\title{
First report of Calonectria tunisiana causing crown and root rot on Eucalyptus globulus
}

\author{
Dalia Aiello $^{1}$ (1) Alberto Fiorenza ${ }^{1} \cdot$ Giorgio Gusella ${ }^{1} \cdot$ Giancarlo Polizzi $^{1}$
}

Received: 22 April 2020 / Accepted: 29 July 2020 / Published online: 10 August 2020

(C) Società Italiana di Patologia Vegetale (S.I.Pa.V.) 2020

Keywords Calonectria tunisiana $\cdot$ Crown and root rot $\cdot$ Eucalyptus globulus

During autumn 2019, a widespread crown and root rot was observed in a commercial nursery in Catania province, Italy, on about 5000 potted 10-12 month-old plants of Eucalyptus globulus Labill. More than $15 \%$ of plants obtained from cutting showed brown to black necrotic lesions on crown, and root were decayed. Discolouration was observed under the bark. Diseased tissues of twenty plants were surface disinfected for $1 \mathrm{~min}$ in $1.5 \%$ sodium hypochlorite solution, rinsed in sterile water, placed on potato dextrose agar (PDA) amended with $100 \mathrm{mg} / \mathrm{l}$ of streptomycin sulfate, and then incubated at $25^{\circ} \mathrm{C}$ for seven days. Calonectria sp. was consistently isolated. Colonies surface and reverse sienna, developed sparse aerial mycelium with abundant cylindrical conidia, rounded at ends, 1 -septate, 47 to $51 \times 4$ to $6 \mu \mathrm{m}$. Conidiophores were stipe septate, hyaline, smooth, 42-95 $\times$ 7-11 $\mu \mathrm{m}$ and phialides were doliiform to reniform, hyaline, aseptate, $8-13 \times 3-5 \mu \mathrm{m}$. Chlamydospores were present. These morphological characteristics were consistent with the original description of C. tunisiana L. Lombard, G. Polizzi \& Crous (Lombard et al. 2011). Part of tef1 gene of CAL-EU1 and CAL-EU2 isolates was amplified using EF1-728F and EF1-986R primers. The sequence data were deposited in GenBank (accession Nos. MT365928 and MT365929). The obtained tef sequences showed $100 \%$ identity with the tester isolate DISTEF-TME1 of C. tunisiana (JN607286). Pathogenicity test was conducted on 6-month-old cuttings of E. globulus. The inoculum consisted of mycelial plug inserted

Dalia Aiello

dalia.aiello@unict.it

1 Dipartimento di Agricoltura, Alimentazione e Ambiente, sezione Patologia Vegetale, University of Catania, Via S. Sofia 100, 95123 Catania, Italy at the crown level. Fifteen plants were used. Control consisted of sterile PDA plugs. Plants were incubated into a growth chamber at $25^{\circ} \mathrm{C}$. The same symptoms observed in field appeared on inoculated plants after 1 month and after 2 months all plants died. The pathogen was re-isolated from the artificially inoculated plants, and identified as previously described. Calonectria species are widespread in Sicily on ornamental crops (Polizzi et al. 2012; Vitale et al. 2013) while $C$. tunisiana was reported only in Tunisia (Lombard et al. 2011). To our knowledge, this is the first report of $C$. tunisiana causing disease on E. globulus and it is the first detection of the pathogen in Europe.

\section{References}

Lombard L, Polizzi G, Guarnaccia V, Vitale A, Crous PW (2011) Calonectria spp. causing leaf spot, crown and root rot of ornamental plants in Tunisia. Persoonia 27:73-79

Polizzi G, Vitale A, Aiello D, Guarnaccia V, Crous PW, Lombard L (2012) First occurrence and characterisation of Calonectria ilicicola causing a new disease on Laurus (Laurus nobilis) in Europe. J Phytopathol 160(1):41-44

Vitale A, Crous PW, Lombard L, Polizzi G (2013) Calonectria diseases on ornamental plants in Europe and the Mediterranean Basin: an overview. J Plant Pathol 95(3):463-476

Publisher's note Springer Nature remains neutral with regard to jurisdictional claims in published maps and institutional affiliations. 